\title{
A Vocational English Teacher's Professional Identity in Industry 4.0
}

\author{
Insyavia Rahayu Setyowati, Nur Arifah Drajati \\ Universitas Sebelas Maret \\ insyaviarahayu@student.uns.ac.id
}

\begin{abstract}
The growth of technology in Industry 4.0 also gives impact to education. Language teachers are not only consumers of commercial educational materials, but also must improve the creativity in managing classrooms. They should find innovative instructional approaches, method, and strategies. Therefore, the language teacher identity (LTI) becomes very important. The teachers should discover the contexts in which their designed practices are rooted and expelled to critize their own personal and professional lives. The current article is a narrative inquiry that an English teacher of vocational high school in Indonesia began to experience over a period of two years during which she could see herself try to find best English learning for students that are ready to work in industry 4.0. Shimmering on self experiences and documenting the activities narratively made the teacher face with a number of teaching tradition that she wants to bridge education to world current development. As the development of technology, She began to see herself transforming from traditional learning into new learning that well matched for millennial students. This experiences become very challanging for teachers who are interested in self inquiry research.
\end{abstract}

Keywords: industry 4.0, narrative inquiry, teacher's identity, technology.

\section{INTRODUCTION}

The teacher identity is the concept of how teachers identify themselves as teachers. It includes who they are as professionals, how they struggle to become who they want to be through a continuous process of reflecting on their classroom practices and experiences. It is not a static entity; a teacher constantly forms and develops a reflective sense of self through looking into his or her practice and life of teaching, as a mirror (Palmer, 1997). Teacher's identity is associated with his or her their unique practices (Gee, 2001).

Teachers' professional identity emerge in teacher's various types of teaching practices in which they construct holistic views of themselves in relation to 
students, colleagues, professional purposes, and circumstances of teaching (Beijaard, Meijer, \& Verloop, 2004; Dillabough, 1999; Olsen, 2008).

Teachers identity is not about "Who am I at this moment?", but also "Who do I want to become?" (Beijaard et al., 2004). Therefore, teachers should constantly explore and reflect on who they are as professionals based on their classroom practices and experiences (Antonek, McCormick, \& Donato, 1997; Brooke, 1994). Teachers should also actively look for new ways to define their professional work to approach important educational issues (Coldron \& Smith, 1999). They shape and improve who they are through reflective story telling about what they strive for and do as teachers: "stories to live by" that are shaped by the past and project into their ongoing lives and works (Connelly \& Clandinin, 2000)

For more fifteen years, I, as a researcher, have worked as an English teacher. Teaching English has been the biggest story in my life. Like many ordinary nonnative English-speaking teachers, I have long lived in a world of educational institutions. I have experienced different approaches and methods, teaching various students from various institutions.

English as an international language is important to my vocational student's life. I was regularly trained to teach the four skills, as well as their sub-skills and strategies. However, teaching English in Vocational school is really differrent with those general high school. Vocational students are prepared to be ready to work in Industry 4.0. They have to master skilss needed at workplaces. The use of technology in this modern education era is a must. Teachers should find their own identity. I need to improve my skill and find new innovations in teaching. I want to make English a contextual subject that well matched to the student's life. For that reason, the teacher should understand the student's life in the industry 4.0. Therefore, hopefully my teacher's experience became the inspiration for this narrative inquiry project. For that reason, the teacher should understand the student's life in the industry 4.0. I prefer to use the new method and various strategy in ELT in modern life.

During the early stages of the project, my activities often included follow up questions about how can I connect ELT and students life, or relate them to their personal and social lives. The vocational students live in technology era. They love 
to study using technology. Then, as I continued my journey, my activities were gradually replaced by more action-based and student-authored performances using technology. This method is more interesting for millennial students.

English is a means to understand instruction in education and its application in the industrial world. English language skills, technological mastery and knowledge are the main demands in the world of work. However, in reality the world of education is still lagging behind in the utilization of technology. There is a gap between knowledge in the school world and the skills needed by the industrial world. One of them is learning English that has not been maximized and the use of technology in learning that is not comprehensive.

The gap must be recognized by the world of education. The teacher must be more reflective, aware of which practices are appropriate for their class. They should also be able to criticize their own personal and professional lives. The identity of professional teachers who keep up with the times becomes very important, especially vocational school (SMK) teachers. Teacher identities are considered to play a key role in the decisions teachers make about their teaching practices, the content they teach and the types of relationships they maintain with their students. Thus, the teacher's identity is recognized as an analytical lens that is used to investigate various aspects of teacher teaching performance, the way the teacher integrates various influences from the environment that accumulated from his past, present and what will be done in the future.

Technological Pedagogical and Content Knowledge (TPACK) provides insights for English teachers to optimize three important things for education, namely from the aspects of technology, pedagogy and content. By utilizing this learning framework, the three elements will support each other and produce a comprehensive and meaningful learning process.

This research is a narrative inquiry (narrative inquiry) that analyzes an English teacher from a vocational high school in Indonesia who tries to find the best English learning for vocational students who are ready to work. I reflected on selfexperiences and documented learning. With the development of technology, I began to see myself changing from traditional learning into new learning that 
implements TPACK. This experience was very challenging for teachers who were interested in self inquiry research.

This research will produce an in-depth narrative about the identity of English teachers during the industrial revolution 4.0 at the vocational level with the TPACK framework. More specifically the purpose of this research is to find out the English teacher's identity in Vocational School.

\section{LITERATURE REVIEW}

This narrative inquiry includes moments of epiphanies that I experienced over a period of two years, while I teach "bad boys" in my classes. As a woman, it is not easy to teach vocational students that all students are boys. Furthermore, English is a very difficult material for students. I try so hard to find a method and strategy to make them love English.

I had woven around myself as a language teacher, and the challenges I went through in order to make English as a fascinating material. My journey began with the uneasy task to teach English in vocational high school in a village far from town, followed by my hesitations, aspirations, and attempts to infuse more depth, taste, and vision into my teaching for modern students.

Teachers in this era challenge profession that are very vulnerable. Their role in providing knowledge can be replaced by technology. Students can search for their own knowledge from mobile phones as the products of industrial revolution 4.0 .

That is why the direction of education and educational methods must begin to be changed. How can humans compete with machines? The solution, teachers, must teach character values, morals, culture, love, thanks to others, creativity, and conversation. These things are not owned by the machine resulting from the 4.0 industrial revolution. Social engineering is needed by incorporating old value elements to immediately go to industry 4.0 that accepts moral values and humanism. We must be aware in the future, that competition is not about knowledge anymore, but about wisdom, experience, survival in the era of technology that moves very fast. Here, the teacher's identity becomes very important. 
There were invariably complicated days that did not go as well as my imagination or hoped. As an autobiographical exploration, my narrative inquiry is based on self-observation and self-evaluation through both hand-written and electronic reflective journals. Such reflective journals often involved narrating behind-the-scene actions, such as the progression I went through in selecting the stories, where my ideas came from, why and how I decided to act on them and rebuilt what happened to my classroom on a daily basis.

There are many researchers who study the teacher's identity. However, there is only few research focused on vocational school. This study tries to understand the language teacher's identity in a vocational school. Teachers need to improve professionalism towards 21 st Century education, regarding mentality, commitment, and quality in order to have competence in accordance with the development of the Industrial Revolution 4.0 era.

\section{METHODOLOGY}

\section{Narrative inquiry}

The current effort stands for teachers' narrative inquiry stated by Barkhuizen, Benson, \& Chik (2014) as bringing storytelling and research together either by using stories as research data or by using storytelling as an instrument for data analysis or manifestation of findings'. As stated, 'the most important power of narrative inquiry is in its focus on how people make use of stories to make reasonable of their practices in the field of inquiry where it is essential to know phenomena from the perspectives of those who go through them.

Narrative inquiry in ELT focuses on the teaching practice process, about how one compiles teaching content subjects. After that, the experience is exposed, hoping to contribute to someone's experience compiling teaching. What isimportant about the narrative investigation is to inform our practice. The experience analysis discussed here is how the researcher's feelings and circumstances compile teaching.

The importance of narrative inquiry, especially when written in teachers' own writing in the form of autobiographies, reflective journals, and/or diaries, lies in what Johnson and Golombek (2011) call its 'transformative power'. As teachers become self-critics of their own individual and specialized lives, they improve their 
consciousness of their rationale connections with students, possible congruencies, inconsistencies between what they trust, recognize, and consider and what they do in their classrooms. In other words, when revealing one's life story or chapters of it, individuals convey to others a sense of who they are, and what beliefs or values they subscribe to (Barkhuizen, 2013; Johnson, 2007; Nunan, \& Choi, 2010; Pavlenko, 2002; Tsui, 2007; Webster, \& Mertova, 2007).

Bell (2002) argues that narrative inquiry is more than telling or retelling stories as it requires an analytic examination of the underlying insights and assumptions that the story illustrates (p. 208). In the same way, Johnson and Golombek (2011) argue that teacher-authored narratives can be transformative as they create meditational spaces for teachers to externalize their perceptions of highly developed issues, stated their beliefs through theoretical constructs, interpret their experiences, and notice issues that would have stay obvious. Finally, narratives impart fertile ground for discover language teachers' negotiable and nonnegotiable dilemmas, struggles, and epiphanies affecting their identity construction, as well as changes they are going through (Abednia, 2012; Harbon \& Moloney, 2013).

Unfortunately, teachers' stories have often remained unheeded or unappreciated amidst dominant theories of teaching and learning, principles, mandates, and standards of performance (Barkhuizen, 2011; Freeman, 2007). Therefore, it is essential for ELT teachers to write their experiences into narrative inquiry research.

This is an authobiographical research that analyzes an English teacher from a vocational high school in Indonesia who develop the professional identity. I, as a researcher, reflect the experiences and documented learning as an autobiography. With the development of technology, I began to see myself changing from traditional learning into new learning by implementsing TPACK. This experience was very challenging for teachers who were interested in self inquiry research. 


\section{Teacher's Identity}

Language teacher identity (LTI) indexes both social structure and human agency, which shift over historical time and social context. Also are important are the language teacher's hopes and desires for the future and their imagined identities (Norton). The more central a belief and more connected to their emotions, the more influential it is to the identities.

The investigation of teacher's identity formation as a teacher was conducted through a narrative inquiry. Connelly and Clandinin (1999) stated that the teacher's professional identity in terms of "stories to live by" (p. 4). They then explained that the stories offer a narrative tale that teachers employ their experience to make sense and useful as Beijaard et al. (2004) explained that in storytelling, teachers connect theory narratively. Based on that, teachers can further determine and figure their professional identity is ensuing in new or diverse stories. (p. 121). Teacher's narrative was constructed and reconstructed over two years. It started with storytelling then prolonged and restricted through teacher's reflective diaries, which she wrote for herself.

In analyzing, the data were managed in the nextmode. First, the researcher sorted the data chronologically from the experience of her two years in teaching. Second, the researcher selected the data in relation to the identity that she practiced. For instance, the problems she skilled as an EFL learner and as an EFL teacher were selected and the interactions between those divergences were analyzed. The process concerned restructuring the flashbacks that she used as she described the psychological efforts. It also reconstructed experiences when she was a learner and a teacher. The last, researcher analyzes the data in line with the scaffold of the dual process of identity formation are identification and negotiability of meanings. Specifically, the parts that are studied: figure and basis of reward, involvement, and noninvolvement in reification, negotiability, and no negotiability of significances and involvement and noninvolvement in the negotiation of significances. Once more, the connection between the means was studied.

Trent (2017) also elaborates on teacher identity formation positing that teachers engage in four dimensions of identity construction including discursive, experiential, negotiated, and contested dimensions. According to Van Lankveld, 
Schoonenboom, Volman, Croiset, and Beishuizen, (2017), teacher identity is most optimally developed under four circumstances: (a) when teachers feel a sense of appreciation for their work, (b) when teachers experience a sense of connectedness to other community members, (c) when teachers experience a sense of competence in the teacher role including when this sense is acknowledged by others, and finally, (d) when teachers are provided with the opportunity to envisage their future career paths as teachers.

As the above conceptualizations indicate, teacher identity is a kaleidoscopic understanding of self, constructed when teachers' personal characteristics, including their past experiences, and cultural, historical, social, institutional, and environmental factors interact.

\section{FINDING}

\section{A Different Me}

Language teacher's identities are cognitive, social, emotional, ideological and historical. Throughout this project, I had the chance to re-visit my understandings, critique myself, re-enact my role as a materials developer, and rethink what I do as a teacher. Needless to say, on some occasions, my fear of change intimidated me to move back and forth between my institutionalized being and a new, emerging one.

I love teaching. Being in class is my happiness, it is my destiny. To teach means to open the student's heart to knowledge and wisdom. So, it is a noble profession. By teaching, I can be a useful person.

In light of my personal struggles, my contacts with the students of vocational school, I began to see myself moving away from being a traditional teacher to being a modern teacher, and from being an inelastic teacher to an elastic teacher. Furthermore, I could see myself moving from the domain of words to the wider realm of worlds, and from fragmented practices to more interconnected ones. 


\section{From Material Focus to Emotional Touch}

I can see myself moving from a teacher who focuses on the material to the teacher who improves the emotions of students to learn. I become a teacher who gives faith and love to students. Fun learning, which uses a variety of methods that are in accordance with themental state of students, makes English a happy learning. I turned into a teacher who wasable to foster a love of students in learning. Willingness to always learn and soft skills areneeded by vocational students in the workforce.

Teaching using TPACK is very challanging. Honestly, I find some difficulties and obstacles. However, as a person who must always study and upgrade the skill, I push myself to continue improving TPACK in my classrooms.

I feel so happy that my students get new experiences in learning. English becomes a lesson taht is very interesting.

"Ifeel very happy to learn using technology. Learning English using a mobile phone is very impressive. I can get complete information and very detailed pictures about Mount Fuji. We seemed to really be there, "said Vicky.

Student's are so fascinated with the using of technology. They enjoy the learning.

"For three years at Vocational School, I met her in class XII. Previously I always thought the English teacher was boring, but after meeting her, the opinion was lost. Finally, I changed that thought. In the past, I was not at all interested in English, always sleepy in class, but a year later, I realized that I liked English. Because She is friendly and cheerful, English is fun and full of laughter. Using technology, English is much easier. It is not frightened anymore ...," said Dave.

Although information technology is developing so fast in industry 4.0 and learning resources are so easily obtained, the role of teachers as educators cannot be replaced by the advancement of these technologies. The main task of the teacher is to educate, teach, guide, direct, train, assess, and evaluate each student. Therefore, 
the teaching profession is very attached to integrity and personality; the teacher is not only responsible for transferring knowledge to students. In industry 4.0, the teacher brings moral values and humanism in the learning process.

"She is an English teacher who has different teaching methods than other teachers. The way she taught in class always attracted us. Even though she knew we sometimes had difficulty understanding the lesson, but patiently, he always smiled to guide us. Aside from being a teacher, we also become friends. Friends who are willing to exchange life stories with us. She knows that we like using technology. We make video, we have Instagram and Youtube channel. It is cool, " said Lia.

She also really understands what is felt by his students. She can make the mood of students to be happy in learning. She is a unique person, a strong and independent mother," said Andy.

The task of the teacher as an educator is to instill the fundamental values of character development of students in their lives, including in the wise use of information technology progress and as an inspiration for their students. Teachers should not just blame the enormity of the development of information technology, but be able to direct the positive potential of that progress.

\section{From Traditional to Modern}

Nowadays, knowledge can be obtained from anywhere. Nowadays, children are more interested in learning from gadgets. These small, sophisticated machines never got angry at them, never snapped, never showed fatigue and complaints. Even with gadgets, knowledge can be accessed anytime, anywhere, under any circumstances. You don't have to wear a full uniform; you don't have to sit all day in a hard wooden chair, you don't have to listen to the teacher for hours talking in a monotonous intonation. No need to rank well to show how much knowledge children are tired of. If children need a piece of knowledge, they can just look for it online. 
In the industrial era, professional teachers are needed, teachers who are able to take advantage of the progress of the superfast information technology to improve the quality of the teaching and learning process in each education unit in order to prepare superior human resources with global competence.

I am not part of the millennial generation. Therefore, to understand students, I have to learn and apply technology in learning. I use the internet, social media like Facebook, YouTube, Instagram and others as a medium for learning English.

Vocational students, not interested in conventional learning: taking notes, listening and sitting for hours. They will be active and learn to do projects that require technology. They were actively involved and very enthusiastic in learning English with the help of modern technology.

"I think the English lessons are boring. Apparently not. It turns out that my teacher is very creative. We can use social media to learn. However, we can make English videos uploaded on Youtube. Cool ...," said Roy.

A teacher cannot ask students to return to their time, because they have their own time. Follow and adventure with them. Use technology as well as love to teach them. From traditional to modern, and from rigid material into emotioal touch. Hopefully, my narrative inquiry and the challenges I faced will inspire other teachers to embark on their own journey of self-inquiry and professional growth.

\section{DISCUSSION}

Based on the stories analysis, the study demonstrates that the language professional identities are deeply corrrelated with the cognitive learning, social culture changes and also emotional changes. Cognitively, the student teachers actively engaged in the construction of their knowledge about language teaching using technology. The lesson plan, material and method are changing. I have to follow this rapid development. I can not use traditional method anymore. For that reason, I must study harder to adapt in cognitive, social, and emotional changes.

Social culture in industry 4.0 is moving fast, technology becomes part of human interaction, also in education. Vocational school must prepare the students 
in entering workplaces. TPACK is the implementation of the professional identity. I use many aplications in classroom practices. I change from using traditional method into modern method. Students love to bring mobile phone in the classroom. They can use many applications and social media in studying English. The English learning become exciting. Students really love the English class.

\section{CONCLUSIONS AND SUGGESTIONS}

Language education should give chances for student teachers to reflect on their identities throughout the education process in the classroom. A teacher must aware of the shifts and tensions in their identities, the factors that influence the development of their identities, as well as ways to cope with these factors in their present and future contexts. Given the complexity of identity construction process for preservice teachers, teacher educators could help facilitate student teachers' identity development by building their capacity to engage in cognitive learning and construct their own knowledge through constant reflection. Teacher educators could also be more aware of the social dimension of identity construction by looking at the sites of teacher learning various social and professional networks, into their curriculum

(This article had been presented in Qualitative Research Converence at Syariah Hotel Solo with Gary Barkhuizen, 2019)

\section{REFERENCES}

Abednia, A. (2012). Teachers' professional identity: Contributions of a critical EFL teacher educa-tion course in Iran. Teaching and Teacher Education, 28, 706-717.

Barkhuizen, G. (2011). Narrative knowledging in TESOL. TESOL Quarterly, 45, 391-414. Barkhuizen, G. (Ed.). (2013). Narrative research in applied linguistics. Cambridge: Cambridge University Press. 
Barkhuizen, G., Benson, P., \& Chik, A. (2014). Narrative inquiry in language teaching and learn-ing research. New York: Routledge.

Bell, J.S. (2002). Narrative inquiry: More than just telling stories. TESOL Quarterly, 36, 207-213.

Canagarajah, S. (2012). Teacher development in a global profession: An autobiography. TESOLQuarterly, 46, 258-279.

Freeman, M. (2007). Life 'on holiday'? In defense of big stories. In: M. Bamberg (Ed.), Narrative: State of the art (pp. 155-164). Amsterdam: Benjamins.

Ghahremani Ghajar, S., \& Mirhosseini, S.A. (2011). Whose knowledge? Whose language?: Reeds crying tales of separation. In: S. Ghahremani Ghajar, \&

S.A. Mirhosseini (Eds.), Confronting academic knowledge (pp. 217-233). Tehran: Iran University Press.

Ghahremani Ghajar, S., \& Mirhosseini, S.A. (2012). Decolonizing language education research in Iranian universities. In: C. Alvares, \& S.S. Faruqi (Eds.), Decolonizing the university:The emerging quest for nonEurocentric paradigms (pp. 290-308). Pinang: Universiti SainsMalaysia and Citizens International.

Gong, Y., \& Holliday, A.R. (2013). Cultures of change. In K. Hyland \& L. Wong (Eds.), Innovationand change in English language education (pp. 44-57). London: Routledge.

Gray, R. (2005). Using translated first language literature in the second language classroom, The Internet TESL Journal, XI (12). Retrieved from: http://iteslj.org/Techniques/Gray-TranslatedL1Literatue.html (October 2015). 
Harbon, L., \& Moloney, R. (2013). Language teachers' narratives of practice. Cambridge:Cambridge Scholars.

Johnson, K.E. (2007). Tracing teacher and student learning in teacher-authored narratives. TeacherDevelopment, 11, 1-14.

Johnson, K.E., \& Golombek, P.R. (2011). The transformative power of narrative in second language teacher education. TESOL Quarterly, 45, 486-509.

Moen, T. (2006). Reflections on the narrative research approach. International Journal of Qualitative Methodology, 5, 1-11. Retrieved from: http://www.ualberta.ca/ iiqm/back-issues/5_4/pdf/moen.pdf (October 2015).

Nunan, D., \& Choi, J. (Eds.). (2010). Language and culture: Reflective narratives and the emergence of identity. New York/Abingdon: Routledge.

Parsaiyan, S.F., Ghahremani-Ghajar, S., Salahimoghaddam, S., \& Janahmadi, F. (2014a). 'You give me a thousand green breathings ...': Crafting literary arts in English language classrooms. Teaching and Learning: The Journal of Natural Inquiry and Reflective Practice, 28, 49-61.

Parsaiyan, S.F., Ghahremani-Ghajar, S., Salahimoghaddam, S., \& Janahmadi, F. (2014b). Inquiring 'Tree of Life' at home: Persian literature in English classes. English Teaching: Practice andCritique Journal, 13, 89-109. 